\title{
ANTAGONISTIC BACTERIA AGAINST SCHIZOPHYLLUM COMMUNE FR. IN PENINSULAR MALAYSIA
}

\author{
ANTARJO DIKIN', KAMARUZAMANSIJAM',JUGAHKADIR' ANDIDRISABUSEMAN ${ }^{2}$ \\ 'Department of Plant Protection, Faculty of Agriculture, Universiti Putra Malaysia, 43400 UPM \\ Serdang, Selangor D.E, Malaysia \\ ${ }^{2}$ Plant Pathology and Weed Science Group, Biological Research Division Malaysian Palm Oil Board, \\ 43000 Kajang, Selangor, D.E. Malaysia
}

\begin{abstract}
Schizophyllum commune Fr., is one of the important fungi, causes brown germ and seed rot of oil palm. Biodiversity of antagonistic bacteria from oil palm plantations in Peninsular Malaysia is expected to support in development of biopesticide. Isolation with liquid assay and screening antagonistic bacteria using dual culture assay were carried out in the bioexploration. A total of 265 bacterial isolates from plant parts of oil palm screened 52 antagonistic bacterial isolates against 5. commune. Bacterial isolates were identified by using Biolog* Identification System i.e. Bacillus macroccanus, B. thermoglucosidasius, Burkholderia cepacia, B. gladioli, B. multivorans, B pyrrocinia, B. spinosa, Corynebacterium agropyri, C. misitidis, Enterobacter aerogenes, Microbacterium testaceum, Pseudomonas aeruginosa, P. citronellolis, Rhodococcus rhodochrous, Serratia ficaria, Serratia sp., S. marcescens, Staphylococcus sciuri, Sternotrophomonas maltophilia.
\end{abstract}

Key words : Schizophyllum commune, biodiversity, antagonistic bacteria

\section{INTRODUCTION}

Schizophyllum commune Fr. causes brown germ and seed rot. Heavy infection decreased seed germination of oil palm about 60 percent (Dikin et al. 2003). Proper seed treatments are required for the control of $S$. commune in the oil palm seeds. Some synthetic fungicides were applied to reduce the loss of germination due to this pathogen, but the negative impact from toxic chemicals to the environment was difficult to avoid. The utilization of bacteria as biological control agents successfully controlled plant pathogen (Sharga and Lyon 1998; Bapat and Shah 2000).

Many studies in exploration of beneficial organisms have been carried out such as Pseudomonas fluorescent for the control of Fusarium wilt of tomato (Dekkers et al. 1998). Streptomyces halstedii (K122) and S. coelicolor (K139) to inhibit the fungi belonging to Oomycetes, Zygomycetes, Deuteromycetes, Ascomycetes and Basidiomycetes (Frandberg and Schnurer 1998). Bacillus subtilis suppressed phytopathogenic microorganism (Phae et al. 1990).

The isolation of antagonistic bacteria was early stage for development of biopesticide such as Pseudomonas fluorescent from rhizospheres (Dekkers et al. 1998), Bacillus licheniformis from leaves of citrus orchard at Letaba Estates,

Corresponding address : antario_dikin@yahoo.com 
Tzaneen (Jager and Kosten 1998), Streptomyces halstedii (K122) and S. coelicolor (K139) from cereal grains (Frandberg and Schnurer 1998), Bacillus subtilis from the composts (Phae et al. 1990), and Burkholderia cepacia from infected oil palm seeds (Dikin et al. 2003). The liquid assay technique was a simple method for isolation of bacteria. Fluorescent Pseudomonas from Pythiumdiseased tulip roots was isolated by extraction of infected root in sterilized water (Weststeijn 1990).

Malaysia is well known as a mega-biodiversity country with complex microbial association. The exploration of beneficial bacteria from oil palm plantations is expected to utilize the antagonistic bacteria from the same ecology of the oil palm pathogen itself.

The purposes of the study were to isolate and to screen the antagonistic bacteria from different plant parts of oil palm for the control of Schizophyllum commune.

\section{MATERIALS AND METHODS}

\section{Cultural Schizophyllum commune Fr. and plant part of oil palm}

The culture of $S$. commune was isolated from heavy infection of oil palm seeds. The fungus was confirmed based on their morphological characteristics and the pathogenic fungus of oil palm (Alexopoulus et al. 1996). The fungal isolate was sub-cultured onto PDA medium for further study.

Randomized samples of plant parts such as fruits, seeds, rhizosphere, and plant debris were collected from oil palm fields in Selangor (UPM, Bangi, Kajang and Seri Kembangan), Guthrie, Layang-Layang, Johor in Peninsular region, Malaysia. Plant parts were used for isolation of potential bacteria.

\section{Isolation of Antagonistic Bacteria}

Plant parts of oil palm such as fruits, seeds, rhizospheres and plant debris were rinsed with tap water to remove the adhered soil on surface. Mesocarp of fruits, endosperm of seeds, and rhizosphere were sliced into $0.5-1.0 \mathrm{~cm}^{2}$ and then 50 g sliced plant parts were placed into 250 $\mathrm{mL}$ Erlemeyer flask added with $100 \mathrm{~mL}$ distilled water. Plant debris with 5. commune was collected under oil palm tree. Ten g of plant debris were cut off in size $1 \mathrm{~cm}$ and then transferred into a $250 \mathrm{~mL}$ Erlemeyer flask added with $100 \mathrm{~mL}$ sterilized water. Sample materials in flasks were placed on electric rotator at $100 \mathrm{rpm}$ overnight at $26 \pm 2^{\circ} \mathrm{C}$. Fold serials $\left(1 \mathrm{O}^{\wedge}-\mathrm{lO}^{\prime{ }^{4}}\right)$ dilutions of suspension were made, $0.5 \mathrm{~mL}$ suspension from each diluted suspension was streaked on King's B (KB) and Nutrient Agar (NA) agar media plates. Plates were incubated at $26-28^{\circ} \mathrm{C}$ for 48 hours. Bacterial colonies on plate were purified by streaking single bacterial colony onto NA medium plates. Each pure culture of bacteria was screened for the antagonistic bacteria based on dual culture (Dikin et al. 2002;Montealegree/a/. 2003). 


\section{Screening the antagonistic bacteria}

Screening of bacterial antagonist was carried out using dual culture assay. One 6-mm diameter of $S$. commune agar plug was placed at the centre of PDA medium in a Petri dish with $9 \mathrm{~cm}$ diameter. Bacterial isolate was streaked on PDA medium with a distance of $2.5 \mathrm{~cm}$ between $S$. commune agar plug and bacterial isolate. Plates were incubated for 7 days at $26 \pm 2{ }^{\circ} \mathrm{C}$. The percentage of radial inhibition growth was measured with the formula:

PIRG $(\%)=(1$ - (fungal growth near to bacterial isolate /fungal growth other side at the same plate as control) $)$ x $100 \%$.

Each treatment was replicated 3 times. Receded data were analyzed using SAS ${ }^{\circ}$ Software. Treatment effect was tested by ANOVA and the means compared using Least Significant Different Test at 5\% probability level (Okamoto et al. 1998; Anonymous 1999; Montealegreefa/. 2003).

\section{Identification of antagonistic bacteria}

Potential antagonistic bacterial isolates were identified by Biolog ${ }^{\circledR}$ identification system which followed the Biolog's procedures. Bacterial suspension was inoculated into GN or GP micro plates depending on gram reaction cluster, $145 \mathrm{uL}$ per well using the 8-channeI repeating pipette. Microplate was covered with its lid and incubated at $28-30^{\circ} \mathrm{C}$ for 24 hours to allow the utilization of carbon sources. Reading result was directly done after inserting the incubated microplate into the Biolog's reader apparatus and its installed micro soft ware of Biolog® identification system for identifying bacteria up to the species level (Anonymous 2001).

\section{RESULTS AND DISCUSSION}

\section{Isolation of antagonistic bacteria}

The number of bacterial isolates was extracted from samples of seeds, fruits, rhizospheres and plant debris of oil palm which grew on KB and NA media. A total of 265 bacterial isolates from plant parts of oil palm were found from different locations, Peninsular region, Malaysia. Separation of bacterial isolates was based on the morphological colony performance such as colony colour, elevation, the margin of colony and colony surface (Hayward 1983).

Isolation of potential bacteria from plant parts of oil palm using liquid assay was effective and simple technique. The liquid assay and the agar plate media are commonly used for isolation of pathogenic bacteria from infected plant parts. Bacterial isolates from different plant parts of oil palm on NA and KB media grew well on the cultural plates.

Dual culture assay screened 52 out of 265 bacterial isolates against $S$. commune. The number of antagonistic bacteria from each location isolated from different plant parts is presented in Table 1. 
BIOTROPIA VOL. 13 NO. 2, 2006

Table 1. Number of bacterial isolates and antagonistic bacteria from plant parts of oil palm were obtained from different locations of Peninsular Region, Malaysia

\begin{tabular}{|c|c|c|c|c|}
\hline Locality & $\begin{array}{l}\text { Bacterial } \\
\text { Code }\end{array}$ & $\begin{array}{l}\text { Obtained from } \\
\text { infected }\end{array}$ & $\begin{array}{c}\text { Number of } \\
\text { bacterial } \\
\text { isolates }\end{array}$ & $\begin{array}{l}\text { Number of } \\
\text { antagonists }\end{array}$ \\
\hline UPM Selangor & 1 & Rhizosphere & 10 & 1 \\
\hline UPM Selangor & 6,7 & Rhizosphere & 8 & 2 \\
\hline UPM Selangor & 17 & Rhizosphere & 11 & 1 \\
\hline UPM Selangor & 20,21 & Rhizosphere & 12 & 2 \\
\hline UPM Selangor & 23,24 & Rhizosphere & 9 & 2 \\
\hline UPM Selangor & 31 & Rhizosphere & 8 & 1 \\
\hline UPM Selangor & 50 & Rhizosphere & 10 & 1 \\
\hline Bangi, Selangor & $47,48,49$ & Rhizosphere & 12 & 3 \\
\hline Seri Kembangan, Selangor & 51 & Rhizosphere & 7 & 1 \\
\hline Kajang, Selangor & 52 & Rhizosphere & 9 & 1 \\
\hline Sub total of rhizosphere (1): & & & 96 & 15 \\
\hline \multicolumn{5}{|l|}{ Layang - Layang, Johor } \\
\hline \multirow{2}{*}{ Layang - Layang, Johor } & 3,5 & Rotten fruit & 8 & 2 \\
\hline & 9 & Rotten fruit & 6 & 1 \\
\hline UPM Selangor & 25,34 & Rotten fruit & 6 & 2 \\
\hline Bangi, Selangor & 35,36 & Rotten fruit & 5 & 2 \\
\hline Kajang, Selangor & 38 & Rotten fruit & 7 & 1 \\
\hline Seri Kembangan, Selangor & & & & \\
\hline \multirow{2}{*}{ Seri Kembangan, Selangor } & 40 & Rotten fruit & 6 & 1 \\
\hline & 41 & Rotten fruit & 5 & 1 \\
\hline Sub-total of fruit (2): & & & 43 & 10 \\
\hline Layang - Layang, Johor & 4 & Seed & 4 & 1 \\
\hline Layang - Layang, Johor & 12,13 & Seed & 5 & 2 \\
\hline UPM Selangor & 18,22 & Seed & 7 & 2 \\
\hline UPM Selangor & 26 & Seed & 5 & 1 \\
\hline Seri Kembangan, Selangor & 37 & Seed & 6 & 1 \\
\hline Bangi, Selangor & 39 & Seed & 5 & 1 \\
\hline Kajang, Selangor & 46 & Seed & 5 & 1 \\
\hline Sub-total of seed (3): & & & 37 & 9 \\
\hline UPM Selangor & 2 & Plant debris & 6 & 1 \\
\hline UPM Selangor & 8 & Plant debris & 8 & 1 \\
\hline UPM Selangor & 10,11 & Plant debris & 9 & 2 \\
\hline UPM Selangor & 14,15 & Plant debris & 8 & 2 \\
\hline Seri Kembangan, Selangor & 16 & Plant debris & 6 & 1 \\
\hline Seri Kembangan, Selangor. & 19 & Plant debris & 6 & $i$ \\
\hline UPM Selangor & 27,28 & Plant debris & 7 & 2 \\
\hline UPM Selangor & 29,30 & Plant debris & 8 & 2 \\
\hline Seri Kembangan, Selangor & 32 & Plant debris & 5 & 1 \\
\hline Seri Kembangan, Selangor & 33 & Plant debris & 6 & 1 \\
\hline Bangi, Selangor & 42 & Plant debris & 7 & 1 \\
\hline Kajang, Selangor & 43,44 & Plant debris & 8 & 2 \\
\hline Kajang, Selangor & 45 & Plant debris & 5 & 1 \\
\hline Sub-total of plant debris (4): & & & 89 & 18 \\
\hline Total $(1+2+3+4):$ & & & 265 & 52 \\
\hline
\end{tabular}


Based on Table 1, 96 bacterial isolates as the highest number were obtained from the rhizosphere followed by plant debris, 89 isolates. The average number of bacterial isolates from rhizosphere was 9.6 followed by 6.8 from plant debris, 6.1 from fruits, and 5.2 from seeds. The bacterial isolates obtained from plant debris were more diverse with the number of bacterial isolates higher than other plant parts such as rhizophere, fruit, and seed.

Eighteen out of 89 antagonistic bacterial isolates were obtained from plant debris, followed by 15 out of 96 isolates from rhizosphere, 10 out of 43 isolates from fruit, and 9 out of 37 isolates from seed. The probability for isolation of antagonistic bacteria from each plant part was 20.2 percent, 15.6 percent, 23.2 percent, and 24.3 percent, respectively.

More dominant bacteria in the rhizosphere and plant debris than seeds and fruits were due to the different available nutrition and the requirement for bacterial growth. Dominance of bacteria in the rhizospheres and plant debris was due to complex interaction between microorganisms and plant parts. Plant debris such as decayed empty bunch, fronds, and rachis were good media for the fungal growth. Blotching symptom with water soak and brown colour in the fruiting bodies of $S$. commune was the indication of interaction between fungus and bacteria.

Dual culture assay of $S$. commune against antagonistic bacteria is presented in Figure 1.

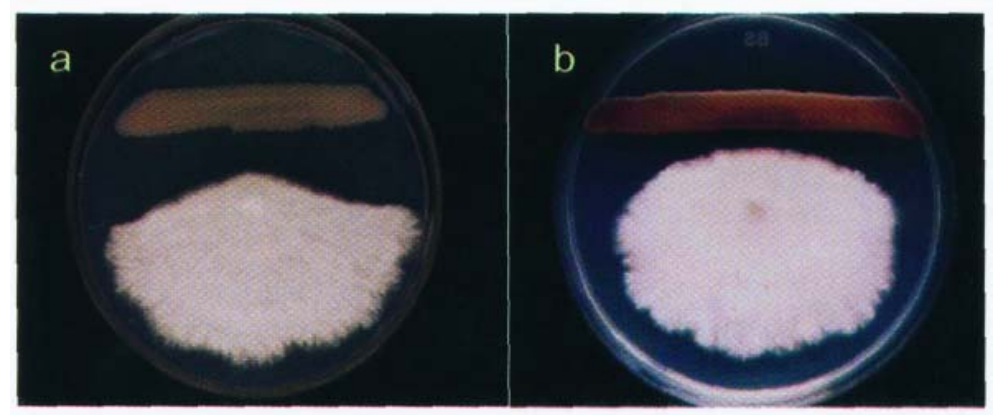

Figure 1. a. Burkhoderia multivorans (bacterial code-50) inhibits the growth of $S$. commune on dual culture of PDA medium at 7-day after incubation at $26 \pm 2^{\circ} \mathrm{C}$

b. Burkholderia cepacia inhibits the growth of $S$. commune on dual culture of PDA medium at 7-day after incubation at $26 \pm 2^{\circ} \mathrm{C}$

Among 52 isolates from different plant parts and different sampling locations inhibited the mycelial growth of $S$. commune with various percentages of radial inhibition. Each bacterial isolate with radial growth inhibition of $S$. commune is presented in Table 2.

The range of radial growth inhibition of antagonistic bacteria was 3.3 percent up to 95.2 percent from the bacterial code 29 and 10, respectively. In Table 2, there are 7 bacterial isolates with highest mean percentage of radial growth inhibition with the bacterial code 10, 8, 9, 14, 50, 7, and 2 with the percentage of inhibition of 95.2, 
BIOTROPIA VOL. 13 NO. 2,2006

Table 2. Mean percentage of radial growth inhibition of $S$. commune against antagonistic bacteria

\begin{tabular}{cccl}
\hline $\begin{array}{c}\text { Bacterial } \\
\text { code }\end{array}$ & $\begin{array}{c}\text { Radial growth inhibition }(\% \pm \\
\text { standard deviation })^{*}\end{array}$ & $\begin{array}{c}\text { Bacterial } \\
\text { code }\end{array}$ & $\begin{array}{c}\text { Radial growth inhibition }(\% \pm \\
\text { standard deviation })^{*}\end{array}$ \\
\hline 1 & $68.2 \pm 0.5 \mathrm{i}$ & 27 & $37.5 \pm 0 \mathrm{p}$ \\
2 & $81.5 \pm 0.3 \mathrm{bcd}$ & 28 & $75.4 \pm 0.8 \mathrm{efg}$ \\
3 & $68.8 \pm 1.1 \mathrm{hi}$ & 29 & $3.3 \pm 0.4 \mathrm{v}$ \\
4 & $40.3 \pm 0.4 \mathrm{p}$ & 30 & $62.5 \pm 3.8 \mathrm{jk}$ \\
5 & $58.6 \pm 2.7 \mathrm{kl}$ & 31 & $46 \pm 1.6 \mathrm{o}$ \\
6 & $74.9 \pm 1.2 \mathrm{fg}$ & 32 & $51 \pm 1.4 \mathrm{mn}$ \\
7 & $81.8 \pm 0.3 \mathrm{bcd}$ & 33 & $78.7 \pm 3.2 \mathrm{bcdef}$ \\
8 & $90.6 \pm 0.9 \mathrm{a}$ & 34 & $55.7 \pm 4.2 \mathrm{~lm}$ \\
9 & $83.2 \pm 1.4 \mathrm{~b}$ & 35 & $13.9 \pm 0.7 \mathrm{st}$ \\
10 & $95.2 \pm 0.2 \mathrm{a}$ & 36 & $24.3 \pm 1.8 \mathrm{q}$ \\
11 & $68.9 \pm 3.7 \mathrm{hi}$ & 37 & $19 \pm 0.8 \mathrm{r}$ \\
12 & $17.2 \pm 3.2 \mathrm{rs}$ & 38 & $80.3 \pm 1.2 \mathrm{bcd}$ \\
13 & $12.5 \pm 1.9 \mathrm{tu}$ & 39 & $8.8 \pm 0.7 \mathrm{u}$ \\
14 & $83.1 \pm 0.2 \mathrm{~b}$ & 40 & $79.4 \pm 5.7 \mathrm{bcdef}$ \\
15 & $48.8 \pm 1.6 \mathrm{no}$ & 41 & $20.3 \pm 0.4 \mathrm{qr}$ \\
16 & $62.6 \pm 1.8 \mathrm{jk}$ & 42 & $75.5 \pm 5.3 \mathrm{efg}$ \\
17 & $78.8 \pm 1.6 \mathrm{bcdef}$ & 43 & $80.6 \pm 0.9 \mathrm{bcd}$ \\
18 & $78.3 \pm 1.2 \mathrm{~cd}$ & 44 & $17.5 \pm 0.8 \mathrm{rs}$ \\
19 & $51.1 \pm 4.4 \mathrm{mn}$ & 45 & $20 \pm 0.8 \mathrm{qr}$ \\
20 & $40 \pm 1.6 \mathrm{p}$ & 46 & $19.3 \pm 0.5 \mathrm{r}$ \\
21 & $39.7 \pm 2.9 \mathrm{p}$ & 47 & $60 \pm 0 \mathrm{kl}$ \\
22 & $65.5 \pm 4.1 \mathrm{ji}$ & 48 & $20 \pm 0 \mathrm{qr}$ \\
23 & $73.3 \pm 4.8 \mathrm{hg}$ & 49 & $58.3 \pm 0 \mathrm{kl}$ \\
24 & $65 \pm 5.9 \mathrm{ji}$ & 50 & $83 \pm 0.8 \mathrm{bc}$ \\
25 & $77.4 \pm 1.8 \mathrm{defg}$ & 51 & $80 \pm 1.6 \mathrm{bcde}$ \\
26 & $58.7 \pm 1.0 \mathrm{kl}$ & 52 & $62.4 \pm 1.6 \mathrm{jk}$ \\
\hline
\end{tabular}

"Average of three replications. Means with standard deviation followed by different letters within the column are significantly different $\left(\operatorname{LSD}_{0.05}=4.6 \mathrm{~mm}\right)$.

90.6, 83.2, 83.1, 83, 81.8, and 81.5, respectively. A number of antagonistic bacteria were isolated from plant parts with varied mean percentages of radial growth inhibition against $S$. commune. The bacterial isolates had high radial growth inhibition which were obtained from plant debris, rhizospheres, and fruit.

Many authors have reported that certain antagonistic bacteria suppressed the growth of pathogenic fungus. In vitro study showed that Burkholderia cepacia from tomato's rhizospheres suppressed the growth of Fusarium oxysporum f.sp. lycopersicae stronger than S. commune. In contrast, B. cepacia from rhizhosperes of oil palm suppressed $S$. commune stronger than $F$. oxysporum f.sp. lycopersicae (Kamaruzaman and Dikin 2005). In this case , targeted potential antagonistic bacteria against $S$. commune should be isolated from the area of oil palm plantation.

\section{Identification of antagonistic bacteria}

Identification of antagonistic bacteria against S. commune based on Biolog ${ }^{\circledR}$ Identification system is presented in Table 3. 
Antagonistic bacteria - A. Dikin et al.

Table 3. Antagonistic bacteria based on Biolog* Identification System

\begin{tabular}{|c|c|c|}
\hline Plant Part & Bacterial code & Bacteria \\
\hline \multicolumn{3}{|l|}{ Rhizosphere } \\
\hline & 1 & Burkholderia cepacia \\
\hline & 6 & Corynebacterium agropyri \\
\hline & 7 & Microbacterium testaceum \\
\hline & 17 & Pseudomonas citronellolis \\
\hline & 20 & Bacillus macroccanus \\
\hline & 23 & B. серасіа \\
\hline & 24 & Burkholderia spinosa \\
\hline & 47 & B. серасіа \\
\hline & 49 & Staphylococcus sciuri \\
\hline & 50 & Burkholderia multivorans \\
\hline & 51 & Burkholderia pyrrocinia \\
\hline & 52 & B. серасіа \\
\hline \multicolumn{3}{|l|}{ Fruit } \\
\hline & 3 & B. серасіа \\
\hline & 5 & Serratia marcescens \\
\hline & 9 & C. agropyri \\
\hline & 25 & Pseudomonas aeruginosa \\
\hline & 34 & P. aeruginosa \\
\hline & 38 & P. aeruginosa \\
\hline & 40 & P. aeruqinosa \\
\hline \multicolumn{3}{|l|}{ Seed } \\
\hline & 4 & Serratia sp. \\
\hline & 12 & Bacillus thermoglucosidasius \\
\hline & 18 & B. pyrrocinia \\
\hline & 22 & B. серасіа \\
\hline & 26 & $P$. aeruginosa \\
\hline & 37 & Sternotrophomonas maltophilia \\
\hline \multicolumn{3}{|l|}{ Plant debris } \\
\hline & 2 & S. mallophilia \\
\hline & 8 & Burkholderia gladioli \\
\hline & 10 & B. gladioli \\
\hline & 11 & B. серасіа \\
\hline & 14 & C. agropyri \\
\hline & 16 & Serratia ficaria \\
\hline & 19 & Enterobacter aerogenes \\
\hline & 28 & B. qladioli \\
\hline & 30 & P. aeruginosa \\
\hline & 33 & Corynebacterium masitidis \\
\hline & 42 & M. testaceum \\
\hline & 43 & Rhodococcus rhodochrous \\
\hline
\end{tabular}

Table 3 presents the identified bacteria and non-identified bacteria by using Biolog Identification system. In the rhizosphere 12 identified species and 3 non-identified species were found. The identified species from rhizosphere were B. cepacia, C. agropyri, M. testaceum, P. citronellolis, B. macroccanus, B. spinosa, S. sciuri, B. multivorans, and B. pyrrocinia. Among 9 species, the dominant identified species in the rhizosphere was B. cepacia. 
Seven identified species and 3 non-identified species of antagonistic bacteria were found in fruits. The identified species from fruits were $B$. cepacia, $S$. marcescens, $C$. agropyri, and $P$. aeruginosa. Among the 4 species, the dominant identified species in the fruit was $P$. aeruginosa.

$P$. aeruginosa was isolated from the rhizospheres and plant debris. This bacteria was recognized as the supplier of mineral which was required for metabolism process of plant from the access of bacterial metabolites (Hofte et al. 1993; Abdullah et al. 2003). There were complex microorganisms around rhizospheres to compete with each other for survival which showed the synergism and antagonism interaction. Infected plant debris with $S$. commune around the rhizosphere was to bait the potential antagonistic bacteria.

Six identified species and 3 non-identified species of antagonistic bacteria in seeds were found. The identified species from fruits were Serratia sp., B. thermoglucosidasius, $B$. pyrrocinia, B. cepacia, $P$. aeruginosa, and $S$. maltophilia. In the plant debris 12 identified species and 6 non-identified were found. The identified species were $S$. maltophilia, $B$. gladioli, B. cepacia, C. agropyri, S. ficaria, E. aeogenes, P. aeruginosa, C. masitidis, M. testaceum, and $R$. rhodochrous. The dominant species from plant debris was B. gladioli.

$B$. cepacia and B. gladioli were dominantly found in the rhizospheres and plant debris, respectively. The presence of $B$. cepacia in the rhizospheres of oil palm was the same evident with the presence of $B$. cepacia in the rhizospheres of banana to protect plant infection caused by Fusarium oxysporum f. sp cubense. B. cepacia colonizes the surface of hyphae and fungal macrospores (Pan et al. 1997). B. gladioli was found in the rhizospheres and potential antagonistic bacteria against $S$. commune, however the implication for biological control was less recognized.

The identified species of antagonistic bacteria from different plant parts were Bacillus macmccanus, B. thermoglucosidasius, Burkholderia cepacia, B. gladioli, B. multivorans, B pyrrocinia, B. spinosa, Corynebacterium agropyri, C. misitidis, Enterobacter aerogenes, Microbacterium testaceum, Pseudomonas aeruginosa, P. citronellolis, Rhodococcus rhodochrous, Serratia ficaria, Serratia sp., S. marcescens, Staphylococcus sciuri, and Sternotrophomonas maltophilia. Out of these species were new recorded species of antagonistic bacteria i.e. B. thermoglucosidasius, B. multivorans, B. spinosa, C. agropyri, C. misitidis, Enterobacter aerogenes, P. citronellolis, Rhodococcus rhodochrous, Serratia ficaria, and Staphylococcus sciuri. However, B. cepacia, B pyrrocinia P. aeruginosa, S. marcescens and S. maltophilia were reported as biocontrol agents (Burkhead et al. 1994; Kobayashi et al. 1995; Suparman et al. 2002; Szczech and Shoda 2004). Avirulent isolate of B. gladioli strain 1064A is used for suppressing the incidence of bacterial seedling blight of rice caused by $B$. plantarii (Miyagawa 2000).

$P$. aeruginosa is grouped as fluorescent Pseudomonads based on the production of a fluorescens pigment on KB medium (Sand et al. 1980). The bacterium produces siderophores as plant growth promoter (Hofte et al. 1993) and broad spectrum antagonistic bacteria against pathogenic fungi (Haas et al. 1991). 
Several species of fluorescent Pseudomonads were known to be antagonistic bacteria and used as biological control agents. $P$. aeruginosa 7NSSK2 was able to suppress Pythium splendens, the causal pre and post-emergence damping-off and root rot of many crops such as tomato (Tambong et al. 1998). P. aeruginosa and S. marcescens were isolated from plant part of oil palm, these isolates were confirmed as biocontrol agent for suppressing Sclerotium rolfsii and Rhizoctonia solani (Ordentliche/a/. 1987).

\section{CONCLUSIONS}

A number of bacterial isolates from plant part such as seeds, fruits, rhizospheres, and plant debris under oil palm trees were potential antagonistic bacteria against $S$. commune. A total of 52 out of 265 bacterial isolates were identified as the antagonistic bacteria against $S$. commune. The identified antagonistic bacteria using Biolog ${ }^{\circledR}$ Identification System were as follows : Agrobacterium agropyri, Bacillus macroccanus, B. thermoglucosidasius, Burkholderia cepacia, B. gladioli, B. multivorans, B pyrrocinia, B. spinosa, Corynebacterium agropyri, C. misitidis, Enterobacter aerogenes, Microbacterium testaceum, Pseudomonas aeruginosa, $P$. citronellolis, Rhodococcus rhodochrous, Serratia ficaria, Serratia sp., S. marcescens, Staphylococcus sciuri, and Sternotrophomonas maltophilia. Some of bacterial isolates were recognized as biocontrol agents of plant pathogenic fungi and the rest of isolates have yet to be studied for their status. All of these species are required for further studies on the production of their secondary metabolites which might be potential substances to inhibit the growth of $S$. commune.

\section{ACKNOWLEGDMENT}

The study is partially supported by IRPA project, Malaysian Government (Vote No. 54400) as part of the Ph.D. thesis of the first author.

\section{REFERENCES}

Abdullah, H., H.M. Saud and C.E. Fong. 2003. Evaluation of the combined effect of Pseudomonas aeruginosa and Penicillmm sp. on the development of bacterial wilt caused by Ralstonia solanacearum on tomato. Abstract. Third Federal of Asia Pacific Microbiology Societies Conference. Kuala Lumpur, October 15-18,2003 Alexopoulos, C.J., C.M. Mims and M. Blackwell. 1996. Introductory Mycology. Phyllum: Basidiomycota. Order: Aphyllophorales. Polypores, Chantharelles, Tooth Fungi, Coral Fungi, and Corticioids. 19 : 563-597. Anonymous. 1999. SAS* Software. System release version 8 (TS Ml), SAS Institute Trial Site, Gary, North California, USA. Anonymous. 2001. A Powerful automated system for the rapid identification of bacteria and yeasts.

Biolog. http://www. biolog.com. Accessed on : March 24 2001. Bapat, S. and A.K. Shah. 2000. Biocontrol of fusarial wilt of pigeon pea by Bacillus brevis. Canadian J.

Microbiol., 46: 125-132. 
Burkhead, K.D., D.A. Schisler and P. J. Slininger. 1994. Pyrrolnitrin production by biological control agent Pseudomonas cepacia B37W in culture and in colonized wounds of potato. Appl. and Environ. Microbiol., 60(6): 2031-2039. Dekkers, L.C., C.P. Bloemendaal, L.A. de Weger, C.A. Wijffelman, H.P. Spaink, B.J.J. Lugtenberg. 1998. A two-component system plays an important role in the root-colonizing ability of Pseudomonas fluorescent strain WCS365. Molec. PI. -Microbe Interaction., 11: 45-56. Dikin, A., Kamaruzaman

Sijam, Zainal Abidin Mior Ahmad, Mohamad Zakaria Hussin and Idris B Abu Seman. 2002. Interaction between Schizophyllum commune and antatonistic bacteria isolated from rotted fruits of oil palm. Malaysian Microbiology Symposium. Kota Bahru. September, 811,2002. Dikin, A., Kamaruzaman Sijam, Zainal Abidin Mior Ahmad and Idris B Abu Seman. 2003. Association of Schizophyllum commune Fr. with oil palm seeds. The $3^{\prime 1}$ National Seed Symposium, Putrajaya, Malaysia. April 8-9,2003. Frandberg, E. and J. Schnurer. 1998. Antifungal activity of chitinolytic

bacteria isolated from airtight stored cereal grain. Canadian J. Microbiol., 44:121-127. Haas, K., C. Keel, J. Laville, M. Maurhofer, T.

Orbenhan-sli, U. Schnider, C. Voisard, B. Wuthrich, G. Defago. 1991. Secondary metabolites of Pseudomonas fluorescens strain CHAD involved in the suppression of root diseases. In Advances in Molecular Genetics of Plant-Microbe Interactions. Vol 1. Proceedings of the $5^{\text {th }}$ International Symposium on the Molecular Genetics of Plant-Microbe Interactions, ed. H. Hennecke, D.P.S. Verma. Netherlands : Kluwer Academic

Bacteria Press.450-456. Hayward, A.C. 1983. Primary differentiation of the genera of plant pathogenic bacteria. In Plant

Diseases A Diagnostic Guide, ed. P.C. Fahy and G.J. Persley. Sydney: Academic Press, p. 13-26. Hofte, M., S.

Buysens, N. Koedan and P. Cornelis. 1993. Zinc affects siderophores-mediated high affinity iron uptake system in the rhizosphere Pseudomonas aeruginosa 7NSK2. Biometals., 6:85-91. Jager, E. D. and L.

Kosten. 1998. Biological control of citrus pre- and post-harvest pathogens. Abstract. 1. 5.2.22. Proceedings of $7^{\text {th }}$ International Congress of Plant Pathology. Scotland. Kamaruzaman Sijam and A.

Dikin. 2005. Biochemical and physiological characterization of Burkholderia cepacia as biological control agent. International Journal of Agriculture and Biology. 7. (3): 385-388. Kobayashi, D.Y., M. Guglielmoni and B.B. Clarke. 1995. Isolation of the chitinolytic bacteria Xanthomonas maltophilia and Serratia marcescens as biological control agents for summer patch disease of turfgrass. Soil Biol. and Chemy., 27: 1479-148. Miyagawa, H. 2000. Biocontrol of bacterial

seedling blight of rice caused by Burkholderia gladioli using its avirulent isolate. Japan Journal of Phytopathology 66: 232-238. Montealegre, J.R., R. Reyes, L.M. Perez, R.

Herrera, P. Silva and X. Besoain. 2003. Selection of bioantagonistic bacteria to be used in biological control of Rhizoctonia solani in tomato. Electron. J. Biotech., 6(2):115-127. Okamoto, H., M. Sato, Z. Sato.Y. Koiso, S. Iwasaki and M. Isaka. 1998.

Identification of antibiotic red pigments of Serratia marcescens F-l-1, a biocontrol agent of damping-off of cucumber, and antimicrobial activity against other plant pathogens. Annual Phytopathology Society. Japan,

the 64:294-298. Ordentlich, A., Y. Elad and I. Chet. 1987. Rhizosphere colonization by Serratia marcescens for

control of Sclerotium rqflsii. Soil Biol. and Biochem
Hastings. 1997. Ultrastructural studies on the colonization of banana tissue and Fusarium oxysporum f.sp. cubense race 4 by the endophytic bacterium Burkholderia cepacia. J. Phytopathol., 145: 479-489. Phae, C.G., M. Sasaki, M. Shoda and H. Kubota. 1990.

Characteristics of Bacillus subtilis isolated from composts suppressing phytopathogenic microorganisms. Soil Sc. PI. Nutr., 36: 555-586. Sand, D.C., M.N.

Schroth and D.C. Hildebrand. 1980. Pseudomonas. In Laboratory Guide for Identification of Plant Pathogenic Bacteria, ed. N.W.Schaad. APS St. Paul. Minnesota, p. 72. Sharga, B.M. and

G.D. Lyon. 1998. Bacillus subtilis BS107 as an antagonist of potato blackleg and soft rot bacteria. Can. J. Microbiol., 44: 777-783. Szczech, M. and M. Shoda. 2004. Biocontrol of Rhizoctonia dampingoff of tomato by Bacillus subtilis combined with Burkholderia cepacia. J. Phytopathol., 152:549-556. 
Antagonistic bacteria - A. Dikin et al.

Suparman, M., Kamaruzaman Sijam, Sariah Meon and Inon Sulaiman. 2002. In vitro screening of antagonistic bacteria against Fusariutn oxysporum f.sp. lycopersici. $25^{\mathrm{m}}$ Malaysian Microbiology Society Symposium. 5* Unesco National Workshop on the Promotion of Microbiology in Malaysia. Kota Bharu, September 8-11,2002. Programme and Abstract, p.24.

Tambong, J.T., G. Vanneste, J. Poppe and M. Hofte. 1998. Increased Suppression of Pythium splendens in Bean (Phaseolus vulgaris) by a Siderophore Negative Mutant of Pseudomonas aeroginosa 7NSK2. 7th International Congress of Plant Pathology. Abstracts-Volume 1. 5.2.19. Edinburgh, Scotland.

Weststeijn, E.A. 1990. Fluorescent Pseudomonas El 1.3 as biological agent for Pythium root rot of tulip. Neth.J. Pl.Pathol., 96:261-272. 